\title{
Effects of Dietary Supplementation of Ginger, Garlic and Onion on Semen Profile, Haematological and Serum Antioxidant Status of Rabbit Bucks Raised in the Dry Season of the Humid Tropic
}

\author{
B. H. Ajao ${ }^{1 *}$ and S. I. Ola ${ }^{2}$ \\ Received: $13^{\text {th }}$ January 2021 / Accepted: $25^{\text {th }}$ November 2021
}

\begin{abstract}
Purpose: The study evaluated the semen, haematological and antioxidant status of rabbit bucks fed ginger, garlic and onion supplemented diets under a severely heat stressed condition. This is to evaluate the effect of heat stress and spice supplementation on seminal parameters, haematology and antioxidant capacity of rabbit buck raised in the tropics.
\end{abstract}

Research Method: Fifty - five bucks were allotted to 11 treatments comprising of control diet, three each of ginger, garlic and onion at $5 \mathrm{~g}, 10 \mathrm{~g}$ and $15 \mathrm{~g} / \mathrm{kg}$ feed plus positive control diet. Seminal, haematological and antioxidant traits of the bucks and their pen's Temperature - Humidity index (THI) were observed for 8 weeks.

Findings: THI $\left(29.30-31.10^{\circ} \mathrm{C}\right)$ recorded during the study indicated the prevalence of severe to very severe heat stress. Heat stress impacted negatively more on sperm morphology than on other seminal parameters. Sperm cell motility, viability and abnormality were similar within supplemented groups and the controls. Semen volume and concentration were highest in animals fed garlic at 10 and $15 \mathrm{~g} / \mathrm{kg}$ feed respectively. Spice supplementation had no significant effect $(p>0.05)$ on the haematology and total antioxidant capacity (TAC) of the experimental animals.

Originality/value: The study concluded that spice supplementation mitigated heat stress effect on sperm cell morphology and was not deleterious on haematology and TAC of the bucks.

Keywords: Antioxidant, Seminal, Supplement, Temperature - Humidity index, Total antioxidant capacity

\section{INTRODUCTION}

In the tropics, high environmental temperatures alone or in combination with high humidity induce heat stress that hampers animal wellbeing and militate against animal productivity (Okab et al., 2008). Hence, heat stress is one of the foremost constraint to rabbit production in Nigeria (Oseni, 2014) because rabbits exposed to elevated ambient temperatures are subjected to imbalances in their thermoregulatory mechanism (Habeeb et al.,1999) leading to, disturbances in feed intake, feed utilization, water metabolism, blood parameters, enzymatic reactions and hormonal secretions.
In male animals, exposure to heat stress hampers spermatogenesis and decreases testosterone levels. Heat stress elevates oxidative stress due to increase in production of reactive oxygen species (ROS), which can lead to DNA damage disruption of cell membrane fluidity and apoptosis of spermatozoa (Hansen, 2009). Consequently, in the rabbit buck, heat stress decreases testosterone concentration, reduces

\footnotetext{
$I^{*}$ Department of Animal Production, University of Ilorin, Ilorin, Nigeria, P.M.B. 1515, Ilorin, Nigeria ajao.bh@unilorin.edu.ng

${ }^{2}$ Department of Animal Sciences, Obafemi Awolowo University, Ile-Ife, Osun State, Nigeria

(Dhttps://orcid.org/0000-0003-0355-9347
} 
libido, disrupts spermatogenesis, and causes apoptosis and morphological abnormalities of sperm cells thereby resulting in reduced or loss of fertility (Finzi et al., 2000).

To attenuate the lethal effect of heat stress on rabbit production and reproduction, farmers have employed managerial, nutritional and physiological approaches (Ayyat et al., 1997). In recent times, however, researchers have focused more on plants due to their antioxidant ability. This is because these plants contain bioactive phytochemicals such as flavonoid, alkaloid and organosulphur compounds which can ameliorate heat stress condition and improve productivity (Pawar and Hugar, 2012) through mopping up ROS and restoration of oxidative damages. The near availability all the year round, relative safety and cheapness of these plants make them a viable replacement to synthetic medicaments. Among the abundant flora in the tropics, Allium sativum (garlic), Zingiber officinale (ginger) and Allium cepa (onion) have shown to have pro growth, fertility (Nagendra et al.,2014) and antioxidant effects (Pawar and Hugar , 2012). Though, these spices are widely used in African folk medicine to sustain human health and fertility, their use have not been well exploited in improving animals' production and health in general and in the rabbit in particular, especially in Nigeria.

Assessment of blood provides the opportunity to ascertain the health status of animals. As a result of this, haematological indices had proved to be an efficient assay of the adverse effect of stress that may emanate from poor nutrition, extreme weather and diseased conditions (Daramola et al., 2005).

Total antioxidant capacity (TAC) is essentially the measure of the amount of free radicals scavenged by a test solution (Rubio et al., 2016) and is indicative of oxidative repair or increased resistance to oxidative damage during circumstances of heat stress or disease (Koracevic et al., 2001). Hence, the determination of TAC embodies an appropriate biochemical index for estimating overall antioxidant status (Nemec et al., 2000).

This study examined the seminal, haematological and antioxidant responses of rabbits fed garlic, ginger and onion supplemented diets. This is to investigate the efficacy of the spices in ameliorating the effect of heat stress in the rabbit in order to improve the welfare and productivity of the animal raised under the humid tropic which is conducive to heat stress.

\section{MATERIALS AND METHOD}

\section{Experimental site and procurement of experimental animals}

Fifty five rabbit bucks aged between $15-20$ months with an average body weight of $1.5 \mathrm{~kg}$ were sourced from repuTable 0farms and the Rabbitary Unit of the Teaching and Research Farm, Obafemi Awolowo University, Ile - Ife, Nigeria where the experiment was conducted. All the bucks were healthy.

\section{Procurement and verification of spices}

Fresh sacks of ginger, garlic and onion, which were the focal test materials were purchased from a vegeTable 0market in Ilorin, Kwara State, Nigeria. The sample of garlic, ginger, and onion were identified and confirmed with vouchers numbered 17735, 17736 and 17737 respectively at the Herbarium, Department of Botany, Obafemin Awolowo University, Ile - Ife.

\section{Experimental design}

The animals sourced outside the Rabbitary Unit of the Teaching and Research Farm, Obafemi Awolowo University, Ile - Ife were acclimatised for 2 weeks before the commencent of the study.

Fifty five of the rabbit bucks were individually housed in metal cages of the dimension $35 \mathrm{~cm} \mathrm{x}$ $42 \mathrm{~cm} \times 54 \mathrm{~cm}$. They were fed with 11 experimental diets which were the basal diet containing no spices (control) and ten others containing ginger, garlic and onion supplements at $5 \mathrm{~g}, 10 \mathrm{~g}$ or $15 \mathrm{~g} /$ $\mathrm{kg}$ feed and the positive control supplemented with 400mg Vitamin $\mathrm{C} / \mathrm{kg}$ (positive control) feed. Water and feed were provided ad libitum in concrete feeders and drinkers moulded with 
openings to permit only the head of the animal to prevent contamination and waste. The experiment lasted for 8 weeks between the months of January and February, 2018 in the dry season.

\section{Monitoring of ambient temperature and relative humidity}

The ambient temperature and relative humidity was measured daily by means of a thermohygrometer from the beginning of the experiment until the end. Both temperature and humidity readings were taken between 11.00 am to 1.00 pm daily when the ambient temperatures were highest. The daily average of the recorded temperature and relative - humidity values for week 0,4 and 8 were used to compute THI of the animals using the equation derived by Marai et al. (2002):

$T H I=t-[(0.31-0.31 \times R H)(t-14.4)]$

Where; $R H=$ relative humidity, $t=$ temperature (degree Celsius).

THI values obtained in the experiment was categorised as observed for the tropics; $<27.8^{\circ} \mathrm{C}$ $=$ absence of heat stress, $27.8-28.9^{\circ} \mathrm{C}=$ moderate heat stress, $28.9-30^{\circ} \mathrm{C}=$ severe heat stress and above $30^{\circ} \mathrm{C}=$ very severe heat stress (Marai et al., 2002).

\section{Collection of seminal, haematological and total antioxidant parameters}

A doe with a disposable artificial vaginal (AV) (Ola, 2016) positioned under it was used to collect semen samples from the selected bucks once a week for the experimental period. Samples were collected between $11 \mathrm{am}$ and $1 \mathrm{pm}$. Semen characteristics were determined according to the procedures of I.R.R.G. (2005) and Al-Eissa et al. (2011).

The semen was collected into a graduated tube attached to the AV to measure the semen volume (SV). $10 \mu \mathrm{L}$ of the semen sample was diluted in ratio 1:100 and charged into the improved Neubauer counter to evaluate sperm count and sperm concentration ( $\mathrm{SCN}$ ) of the ejaculate was calculated.

Adrop of undiluted semen on a warmed glass slide $\left(37^{\circ} \mathrm{C}\right)$ was observed under a light microscope at $\times 400$ magnification to determine percentage motility based on the intensity of the Brownian motion displayed by the sperm cells. A drop of undiluted sperm stained with eosin- negrosin was examined under a microscope at x1000 magnification for both live and dead sperm cells at 5 different microscopic fields and their number expressed in ratio. Similarly, a drop of semen mixed with haematoxylin stain was scrutinized under the microscope at a magnification of $x 1000$ whereby spermatozoa with normal or abnormal morphology were counted from 5 different microscopic fields and expressed in percentages.

Two millilitres of blood samples were collected from 3 bucks from each of the experimental treatments. The samples for haematology were collected from the marginal vein of the bucks' ears into ethylene diamine tetra-acetic acid (EDTA) coated collecting tubes in week 0 and 8 of the experiment. Haematological parameters which include red blood cell, packed cell volume, haemoglobin concentration, mean corpuscular haemoglobin, mean corpuscular haemoglobin concentration, mean corpuscular volume were determined as described by Jain (1986). White blood cell count was determined by the method described by Ewuola and Egbunike (2008). Blood samples for antioxidant status were simultaneously collected from bucks into plain collecting tubes but also collected in week 5 . Serum was extracted from the whole blood by centrifuging at 15,000 rpm. TAC determination was carried out according to the method of Prieto et al. (1998).

\section{Experimental model and statistical analysis}

The experimental model below was used to evaluate the animals' responses in the study:

Yijklm $=\mu+\mathrm{Ai}+\mathrm{Bj}+\mathrm{Ck}+\mathrm{Dl}+\mathrm{Eijklm}$

Yijklm $=$ response variables; $\mu=$ population mean; $\mathrm{Ai}=$ effect of ginger; $\mathrm{Bj}=$ effect of garlic; 
$\mathrm{Ck}=$ effect of onion; $\mathrm{Dl}$ = effect of garlic; Eijklm $=$ residual error

Data was analyzed using the Factorial Analysis Of Variance of the General Linear Model. Values of $\mathrm{P}<0.05$ were considered statistically significant and separated by Duncan Multiple Range Test. The IBM Statistical Package for the Social Sciences version 21.0 software was used for statistical analysis.

\section{RESULTS AND DISCUSSION}

Ambient temperature (AT), Relative-humidity (RH) and Temperature -Humidity Index (THI) fluctuated throughout the experiment (Table 01). AT and RH were significantly higher $(p<0.05)$ at the end of the experiment compared to the beginning contrary to $\mathrm{RH}$ which was lower.

Nonetheless, the fluctuations in ambient temperature and relative-humidity in the dry season were within the ranges that are characteristic of the tropics (Galvin, 2009; Trewin, 2014). THI range of $29.30^{\circ} \mathrm{C}-31.10^{\circ} \mathrm{C}$ indicated that the studied bucks were very severely heat stressed according to the categorisation of Marai et al., 2002. This observation was similar to the conclusions made by researchers in the dry season in both Nigeria and Egypt (Akinsola, 2012; Nizza et al., 2003).

Table 02 showed the seminal parameters of experimental rabbit bucks monitored at a weekly interval. Semen volume, sperm motility and viability were lower in the 1 st week compared to the $2^{\text {nd }}$ week under a very severe THI of $30.68 \mathrm{C}$. At the lower THI of the second week, these parameters improved. This observation is in agreement with the conclusions of Marai et al., 2002 that lower THI was conducive for optimal seminal parameters. On the contrary, sperm concentration was reduced in the $2^{\text {nd }}$ week despite the lowered THI but was statistically similar for the remaining period of the study.

However, seminal parameters with the exception of sperm morphology were sustained for most of the experimental period in spite of high THI in contradiction to the conclusions of El-Maghawry and Soliman, 2002 and Iraqi et al., 2012. From this result, it is apparent that the severe heat stress did not affect spermatogenesis in variance with the observations of Ain-Baziz et al., 2012 and Schneidgenová et al., 2011 both of which reported low sperm parameters at high temperatures and high values at low temperatures.

Table 01: Ambient temperature, relative humidity and temperature -humidity index of the rabbit pen

\begin{tabular}{cccc}
\hline Week & $\mathrm{T}\left({ }^{\circ} \mathrm{C}\right)$ & $\mathrm{RH}(\%)$ & $\mathrm{THI}\left({ }^{\circ} \mathrm{C}\right)$ \\
\hline 1 & $33.90^{\mathrm{b}}$ & $46.71^{\mathrm{ab}}$ & $30.68^{\mathrm{d}}$ \\
2 & $31.94^{\mathrm{a}}$ & $51.43^{\mathrm{bc}}$ & $29.30^{\mathrm{a}}$ \\
3 & $31.63^{\mathrm{a}}$ & $60.43^{\mathrm{d}}$ & $29.51^{\mathrm{ab}}$ \\
4 & $32.21^{\mathrm{a}}$ & $55.23^{\mathrm{c}}$ & $29.73^{\mathrm{b}}$ \\
5 & $33.65^{\mathrm{b}}$ & $48.71^{\mathrm{ab}}$ & $30.59^{\mathrm{cd}}$ \\
6 & $33.70^{\mathrm{b}}$ & $48.29^{\mathrm{ab}}$ & $30.60^{\mathrm{cd}}$ \\
7 & $33.33^{\mathrm{b}}$ & $47.43^{\mathrm{ab}}$ & $30.25^{\mathrm{c}}$ \\
8 & $34.54^{\mathrm{c}}$ & $45.00^{\mathrm{a}}$ & $31.10^{\mathrm{e}}$ \\
SEM $^{*}$ & 0.20 & 1.51 & 0.13 \\
\hline
\end{tabular}

Values within the column with different superscripts are significantly different at $(p<0.05)$. AT $=$ Ambient temperature, $R H=R e l a t i v e-$ humidity, THI = Temperature - Humidity Index, SEM* = Pooled standard error of mean 
Table 02: Weekly seminal parameters of rabbit bucks feed ginger, garlic and onion supplemented diets

\begin{tabular}{ccccccc}
\hline Week & $\begin{array}{c}\text { Volume } \\
(\mathrm{ml})\end{array}$ & $\begin{array}{c}\text { Motility } \\
(\%)\end{array}$ & $\begin{array}{c}\text { Viability } \\
(\%)\end{array}$ & $\begin{array}{c}\text { Sperm Conc. } \\
\left(10^{8}\right)\end{array}$ & $\begin{array}{c}\text { Abnormality } \\
(\%)\end{array}$ & $\begin{array}{c}\text { THI } \\
\left({ }^{\circ} \mathrm{C}\right)\end{array}$ \\
\hline 1 & $0.60 \pm 0.05^{\mathrm{a}}$ & $54.17 \pm 4.03^{\mathrm{a}}$ & $89.39 \pm 2.20^{\mathrm{d}}$ & $7.00 \pm 1.21^{\mathrm{a}}$ & $14.77 \pm 1.79^{\mathrm{a}}$ & $30.68^{\mathrm{d}}$ \\
2 & $0.83 \pm 0.05^{\mathrm{c}}$ & $77.65 \pm 4.22^{\mathrm{b}}$ & $89.64 \pm 2.10^{\mathrm{d}}$ & $3.71 \pm 1.21^{\mathrm{b}}$ & $17.95 \pm 1.56^{\mathrm{a}}$ & $29.30^{\mathrm{a}}$ \\
3 & $0.71 \pm 0.05^{\mathrm{abc}}$ & $75.51 \pm 4.03^{\mathrm{b}}$ & $88.59 \pm 2.15^{\mathrm{cd}}$ & $3.18 \pm 1.24^{\mathrm{b}}$ & $23.66 \pm 1.59^{\mathrm{b}}$ & $29.51^{\mathrm{ab}}$ \\
4 & $0.73 \pm 0.05^{\mathrm{abc}}$ & $79.17 \pm 3.97^{\mathrm{b}}$ & $81.52 \pm 2.14^{\mathrm{ab}}$ & $2.76 \pm 1.21^{\mathrm{b}}$ & $28.71 \pm 1.59^{\mathrm{c}}$ & $29.73^{\mathrm{b}}$ \\
5 & $0.66 \pm 0.05^{\mathrm{ab}}$ & $78.56 \pm 3.93^{\mathrm{b}}$ & $80.57 \pm 2.19^{\mathrm{ab}}$ & $3.53 \pm 1.25^{\mathrm{b}}$ & $35.03 \pm 1.55^{\mathrm{d}}$ & $30.59^{\text {cd }}$ \\
6 & $0.76 \pm 0.05^{\mathrm{bc}}$ & $75.26 \pm 3.92^{\mathrm{b}}$ & $84.92 \pm 2.12^{\mathrm{bcd}}$ & $2.50 \pm 1.23^{\mathrm{b}}$ & $31.79 \pm 1.57^{\mathrm{cd}}$ & $30.60^{\text {cd }}$ \\
7 & $0.78 \pm 0.05^{\mathrm{bc}}$ & $82.15 \pm 3.95^{\mathrm{b}}$ & $84.45 \pm 2.19^{\mathrm{bc}}$ & $3.17 \pm 1.23^{\mathrm{b}}$ & $29.87 \pm 1.74^{\mathrm{c}}$ & $30.25^{\mathrm{c}}$ \\
8 & $0.68 \pm 0.06^{\mathrm{ab}}$ & $82.55 \pm 4.04^{\mathrm{b}}$ & $74.56 \pm 2.21^{\mathrm{a}}$ & $3.43 \pm 1.22^{\mathrm{b}}$ & $31.69 \pm 1.72^{\mathrm{cd}}$ & $31.10^{\mathrm{e}}$ \\
& & & & & & $0.13^{*}$ \\
\hline
\end{tabular}

Values with different superscript within the column are significantly different $(p<0.05), *=$ Pooled standard error of mean of Temperature - humidity index (THI).

This result might be attributed to the inherent adaptability of the studied animals and the experimental diets which might have made the animals' testes and reproductive accessory glands less sensitive to the deleterious effect of heat stress (El-Tarabany et al. 2015). Percentage abnormal sperm cells, contrary to other seminal parameters, increased subsequently at a weekly interval from the $2^{\text {nd }}$ week till the 5 th week (31.79\%) and remained similarly high till the end of the experiment. This observation corroborates the findings of El- Sayed et al., 2016 and could be attributed to the lethal effect of high THI on sperm cell morphology (Chenoweth, 2005; Marai et al., 2002).

Semen volume (SV) increased with level of supplementation from $5 \mathrm{~g}$ to $10 \mathrm{~g}$ inclusion levels in garlic but was similar in onion and ginger groups (Table 03). This was comparable to the findings of El - Speiy and EL-Hanoun, 2013 and at variance with the findings of Ogbuewu et al., 2013. Nonetheless, SV observed at $10 \mathrm{~g}$ inclusion level was not different in both garlic and onion and was similar to the value recorded in ginger at $15 \mathrm{~g} / \mathrm{kg}$ feed implying that garlic and onion inclusion levels were optimal at $10 \mathrm{~g} / \mathrm{kg}$ contrary to ginger which was optimal at $15 \mathrm{~g} / \mathrm{kg}$. Values observed in these inclusion levels corroborated the findings of Pawar and Hugar, 2012 that spice supplementation due to their phytochemicals was effective in sustaining semen parameters under high ambient temperatures. Sperm motility and $\%$ live sperm cells (viability) were similar among the experimental animals in variance to the observations of Ogbuewu et al., 2013. However, this result corroborated the observations of Shinkut et al., 2016 who reported non-significant differences in SM and \% live cells values between the control and the treatments. In garlic supplemented groups, with the exception of garlic at $15 \mathrm{~g} / \mathrm{kg}$ feed, SCN increased as level of inclusion increases similar to the report of Khaki et al., 2009. 


\section{Table 03: $\quad$ Effect of ginger, garlic and onion supplemented diets on seminal parameters of rabbit}

\begin{tabular}{ccccccc}
\hline Treatment & Tl(g) & Volume (ml) & Motility (\%) & $\begin{array}{c}\text { Viability } \\
(\%)\end{array}$ & $\begin{array}{c}\text { Sperm Conc. } \\
\left(\times 10^{8}\right)\end{array}$ & $\begin{array}{c}\text { Abnormality } \\
(\%)\end{array}$ \\
\hline Control & 0 & $0.79 \pm 0.06^{\mathrm{bcd}}$ & $76.54 \pm 4.51^{\mathrm{ab}}$ & $82.88 \pm 2.45$ & $6.60 \pm 1.40^{\mathrm{abc}}$ & $27.67 \pm 1.80^{\mathrm{bc}}$ \\
& 5 & $0.69 \pm 0.06^{\mathrm{abcd}}$ & $76.26 \pm 5.06^{\mathrm{ab}}$ & $86.04 \pm 2.53$ & $5.40 \pm 1.50^{\mathrm{abc}}$ & $26.05 \pm 1.93^{\mathrm{ab}}$ \\
Ginger & 10 & $0.63 \pm 0.06^{\mathrm{ab}}$ & $77.91 \pm 4.54^{\mathrm{ab}}$ & $81.46 \pm 2.45$ & $4.24 \pm 1.40^{\mathrm{ab}}$ & $25.37 \pm 1.92^{\mathrm{ab}}$ \\
& 15 & $0.85 \pm 0.06^{\mathrm{cde}}$ & $83.58 \pm 4.51^{\mathrm{b}}$ & $87.08 \pm 2.45$ & $3.99 \pm 1.40^{\mathrm{ab}}$ & $22.71 \pm 1.80^{\mathrm{a}}$ \\
& 5 & $0.55 \pm 0.06^{\mathrm{a}}$ & $64.58 \pm 4.97^{\mathrm{a}}$ & $86.21 \pm 2.70$ & $2.74 \pm 1.50^{\mathrm{a}}$ & $31.19 \pm 2.07^{\mathrm{c}}$ \\
Garlic & 10 & $0.96 \pm 0.06^{\mathrm{e}}$ & $72.64 \pm 6.07^{\mathrm{a}}$ & $82.96 \pm 2.51$ & $9.70 \pm 1.41^{\mathrm{c}}$ & $29.91 \pm 1.80^{\mathrm{bc}}$ \\
& 15 & $0.52 \pm 0.06^{\mathrm{a}}$ & $78.50 \pm 4.56^{\mathrm{ab}}$ & $85.64 \pm 2.47$ & $2.21 \pm 1.40^{\mathrm{a}}$ & $28.77 \pm 1.84^{\mathrm{bc}}$ \\
& 5 & $0.67 \pm 0.06^{\mathrm{abc}}$ & $81.25 \pm 4.51^{\mathrm{b}}$ & $84.00 \pm 2.45$ & $3.27 \pm 1.40^{\mathrm{ab}}$ & $23.79 \pm 1.80^{\mathrm{a}}$ \\
Onion & 10 & $0.80 \pm 0.06^{\mathrm{cde}}$ & $74.52 \pm 4.52^{\mathrm{ab}}$ & $80.13 \pm 2.45$ & $3.31 \pm 1.40^{\mathrm{ab}}$ & $26.85 \pm 1.83^{\mathrm{ab}}$ \\
& 15 & $0.59 \pm 0.06^{\mathrm{a}}$ & $65.37 \pm 4.64^{\mathrm{a}}$ & $85.07 \pm 2.50$ & $2.23 \pm 1.52^{\mathrm{a}}$ & $24.55 \pm 1.99^{\mathrm{a}}$ \\
Vitamin C & 0.004 & $0.87 \pm 0.07^{\mathrm{de}}$ & $80.73 \pm 5.08^{\mathrm{b}}$ & $84.80 \pm 2.95$ & $6.18 \pm 1.75^{\mathrm{bc}}$ & $26.66 \pm 2.46^{\mathrm{ab}}$ \\
\hline
\end{tabular}

Values with different superscript within the column are significantly different $(p<0.05) T l=$ Treatment level

The low value observed at $15 \mathrm{~g} / \mathrm{kg}$ feed might be as a result of aggregations of some phytochemicals such as saponin of which toxic effect may impair spermatogenesis. SCN in ginger and onion supplemented groups were comparable regardless of level of inclusion and were also similar to the values observed in the control and positive control. This observation is similar to the conclusions of Shinkut et al., 2016 while it was different from the findings of Ogbuewu et al., 2013 who reported that ginger at high levels was deleterious to SCN. Nonetheless, despite the high THI under which this study was conducted, none of the treatments had an SCN lower than the normal range $\left(1.50-5.00 \times 10^{8} / \mathrm{ml}\right)$ for the rabbit (Akpa et al., 2012) which is indicative that the spices sustained spermatogenesis.

Ginger $(15 \mathrm{~g} / \mathrm{kg}$ feed) and onion $(15 \mathrm{~g} / \mathrm{kg}$ feed $)$ supplemented groups were observed to have the lowest values of abnormal sperm cells which implied that ginger and onion were more effective, in comparison to garlic, in ameliorating the lethal effect of severe THI on sperm morphology. This is similar to the report of Khaki et al., 2009, Ige and Akigbe, 2012 and El-Speiy and El-Hanoun, 2013 in similar researches.

However, the percentage of abnormal cells regardless of level of inclusion was high in garlic supplemented groups comparable to the report of Omotoso et al. (2012) and was similar to the values observed in the control and the positive control. The general positive impact of spice supplementation on sperm parameters can be attributed to the spices' antioxidant properties and androgenic effects (Ramandeep et al., 2013; Morakinyo et al., 2010; Hammami et al., 2008) which may have enhanced sertoli cells activities in maintaining sperm production under the influence of heat stress (El-Tarabany et al., 2015).

Table 04 and Table 05 showed the haematological parameters of the experimental bucks before and after the introduction of the spice - supplemented diets at week 0 and week 8 respectively. Red blood cell count (RBC) at the beginning and end of the experiment was not significantly different $(p>0.05)$ among the experimental groups in variance with the observations of Chineke et al., 2006 who attributed the differences that they observed to disparity in breed. At the end of the study, compared to the beginning, RBC was depleted in all the treatments except in groups supplemented with onion at 5 and $10 \mathrm{~g} / \mathrm{kg}$ feed. The reduction was similar to the findings of Shinkut, 2015 and may be due to the effect of heat stress as alluded by NseAbasi et al., 2014. However, the numerically higher RBC value recorded in onion ( $5 \mathrm{~g}$ and $10 \mathrm{~g}$ inclusion levels) 
supplementation was a pointer to improved RBC production which is in agreement with the reports of Najmul, 2015 and Onu and Aja, 2011. This could be attributed to the stimulatory activities of the phytochemicals on cytokines which are believed to be the initiator and regulator in the proliferation of RBC (Enitan et al., 2012). PCV values were not significantly different $(p>0.05)$ among the treatment and control groups at both the beginning and the end of the experiment similar to the findings of Ewuola et al. (2012) but at variance with the findings of Ugwu and Omale, 2011 who reported significant reduction of PCV in rats fed onion and garlic extracts. However, the mean PCV at the end of the study was higher than the mean recorded at the beginning of the study implying that the experimental diets sustained the haematopoiesis process of the animals. Similar to PCV, haemoglobin concentration (Hbc) at both week 0 and 8 were not significantly different among the spice - supplemented groups and the control. The non- significance values of $\mathrm{Hbc}$ among the treatment and the control groups corroborated the result of Oluwole, 2001 and Najmul, 2015 in garlic and ginger treated rats and rabbits respectively, and differed with the conclusions of Enitan et al.,2012 who reported a significant increment in $\mathrm{Hbc}$ due to onion and garlic supplementations.

Table 04: $\quad$ Effect of ginger, garlic and onion on red blood cell count, packed cell volume, haemoglobin concentration and white blood cell count of rabbit bucks fed spice supplemented diets

\begin{tabular}{|c|c|c|c|c|c|c|c|c|c|}
\hline \multirow[b]{2}{*}{ Treatment } & \multirow[b]{2}{*}{$\begin{array}{l}\text { Treat } \\
\text { Level }\end{array}$} & \multicolumn{2}{|c|}{$\begin{array}{c}\mathrm{RBC} \\
\left(10^{6} / \mathrm{mm}^{3}\right)\end{array}$} & \multicolumn{2}{|c|}{ PCV $(\%)$} & \multicolumn{2}{|c|}{$\mathrm{Hbc}(\mathrm{g} / \mathrm{dl})$} & \multicolumn{2}{|c|}{$\begin{array}{c}\text { WBC } \\
\left(10^{3} / \mathrm{mm}^{3}\right)\end{array}$} \\
\hline & & Wk 1 & Wk 8 & Wk 1 & Wk 8 & Wk 1 & Wk 8 & Wk 1 & Wk8 \\
\hline \multirow[t]{2}{*}{ Control } & 0 & $5.92^{\mathrm{ab}}$ & $3.67^{\mathrm{a}}$ & 28.67 & 31.50 & 15.33 & 15.67 & 6.37 & 5.63 \\
\hline & $5 \mathrm{~g}$ & $4.36^{\mathrm{a}}$ & $3.89^{\mathrm{a}}$ & 25.33 & 29.17 & 14.00 & 15.33 & 5.05 & 7.53 \\
\hline \multirow[t]{3}{*}{ Ginger } & $10 \mathrm{~g}$ & $5.90^{\mathrm{ab}}$ & $4.47^{\mathrm{ab}}$ & 24.17 & 31.83 & 15.00 & 15.33 & 6.00 & 6.17 \\
\hline & $15 \mathrm{~g}$ & $6.00^{\mathrm{ab}}$ & $3.96^{\mathrm{ab}}$ & 32.00 & 29.83 & 15.67 & 15.00 & 7.55 & 6.12 \\
\hline & $5 \mathrm{~g}$ & $5.45^{\mathrm{ab}}$ & $5.38^{\mathrm{ab}}$ & 29.33 & 29.50 & 16.00 & 16.00 & 5.52 & 6.22 \\
\hline \multirow[t]{3}{*}{ Garlic } & $10 \mathrm{~g}$ & $6.01^{\mathrm{ab}}$ & $5.14^{\mathrm{ab}}$ & 26.17 & 31.50 & 15.67 & 15.67 & 5.23 & 7.89 \\
\hline & $15 \mathrm{~g}$ & $6.66^{\mathrm{ab}}$ & $4.79^{\mathrm{ab}}$ & 32.67 & 32.00 & 16.33 & 16.00 & 6.03 & 5.87 \\
\hline & $5 \mathrm{~g}$ & $5.54^{\mathrm{ab}}$ & $5.66^{\mathrm{ab}}$ & 26.50 & 31.00 & 15.67 & 15.33 & 8.83 & 6.57 \\
\hline \multirow[t]{2}{*}{ Onion } & $10 \mathrm{~g}$ & $4.97^{\mathrm{ab}}$ & $6.00^{\mathrm{b}}$ & 23.67 & 32.00 & 14.33 & 15.00 & 8.58 & 6.63 \\
\hline & $15 \mathrm{~g}$ & $6.48^{\mathrm{ab}}$ & $4.45^{\mathrm{ab}}$ & 28.00 & 30.00 & 16.00 & 13.67 & 5.93 & 5.78 \\
\hline Vitamin C & $400 \mathrm{mg}$ & $6.88^{\mathrm{b}}$ & $4.56^{\mathrm{ab}}$ & 29.83 & 31.67 & 16.00 & 15.67 & 5.08 & 7.30 \\
\hline SEM* & & 0.22 & 0.20 & 1.17 & 0.55 & 0.28 & 0.25 & 0.48 & 0.30 \\
\hline $\begin{array}{l}\text { Weekly } \\
\text { Mean }\end{array}$ & & 5.77 & 4.79 & $27.85^{\mathrm{A}}$ & $30.91^{\mathrm{B}}$ & 15.46 & 15.33 & 6.38 & 6.52 \\
\hline \pm SEM & & \pm 0.22 & \pm 0.19 & \pm 1.27 & \pm 0.62 & \pm 0.30 & \pm 0.27 & \pm 0.44 & \pm 0.33 \\
\hline
\end{tabular}

Values with different superscript within the column or across the row are significantly different $(p<0.05) ; R B C=R e d$ blood cell; $P C V=$ Packed cell volume; $H b c=$ Haemoglobin concentration; $M C V=$ Mean corpuscular volume; $W k=$ Week, $S E M^{*}=$ Pooled standard error of mean 


\begin{tabular}{|c|c|c|c|c|c|c|c|}
\hline Table 05: & $\begin{array}{l}\text { Effect of g } \\
\text { haemoglol } \\
\text { supplemer }\end{array}$ & $\begin{array}{l}\text { er, garli } \\
\text { concent } \\
\text { I diets }\end{array}$ & $\begin{array}{l}\text { and onio } \\
\text { ition anc }\end{array}$ & $\begin{array}{l}\text { n mear } \\
\text { nean c }\end{array}$ & $\begin{array}{l}\text { iscular } \\
\text { ular vo }\end{array}$ & $\begin{array}{l}\text { oglobir } \\
\text { of rab }\end{array}$ & $\begin{array}{l}\text { In corpuscula } \\
\text { ucks fed spice }\end{array}$ \\
\hline \multirow[b]{2}{*}{ Treatment } & \multirow[b]{2}{*}{$\begin{array}{l}\text { Treat } \\
\text { Level }\end{array}$} & \multicolumn{2}{|c|}{$\mathrm{MCH}(\mathrm{pg})$} & \multicolumn{2}{|c|}{$\mathrm{MCHC}(\mathrm{g} / \mathrm{dl})$} & \multicolumn{2}{|c|}{ MCV (fl) } \\
\hline & & Wk 1 & Wk 8 & Wk 1 & Wk 8 & Wk 1 & Wk 8 \\
\hline \multirow[t]{2}{*}{ Control } & 0 & 25.95 & $43.94^{b}$ & 49.81 & 49.89 & 48.54 & $87.39^{b}$ \\
\hline & $5 \mathrm{~g}$ & 32.78 & $40.19^{\mathrm{ab}}$ & 50.06 & 53.11 & 59.13 & $77.09^{\mathrm{ab}}$ \\
\hline \multirow[t]{3}{*}{ Ginger } & $10 \mathrm{~g}$ & 25.96 & $34.56^{\mathrm{ab}}$ & 53.53 & 49.31 & 42.86 & $72.29^{\mathrm{ab}}$ \\
\hline & $15 \mathrm{~g}$ & 26.79 & $39.05^{\mathrm{ab}}$ & 55.4 & 50.32 & 53.56 & $76.84^{\mathrm{ab}}$ \\
\hline & $5 \mathrm{~g}$ & 30.62 & $29.97^{\mathrm{ab}}$ & 55.54 & 54.28 & 53.81 & $54.98^{\mathrm{a}}$ \\
\hline \multirow[t]{3}{*}{ Garlic } & $10 \mathrm{~g}$ & 26.34 & $30.52^{\mathrm{ab}}$ & 57.13 & 49.79 & 43.64 & $61.38^{\mathrm{ab}}$ \\
\hline & $15 \mathrm{~g}$ & 24.62 & $35.10^{\mathrm{ab}}$ & 58.35 & 50.10 & 49.21 & $70.72^{\mathrm{ab}}$ \\
\hline & $5 \mathrm{~g}$ & 32.68 & $27.16^{\mathrm{a}}$ & 61.91 & 49.7 & 56.69 & $54.75^{\mathrm{a}}$ \\
\hline \multirow[t]{2}{*}{ Onion } & $10 \mathrm{~g}$ & 30.25 & $28.80^{\mathrm{a}}$ & 68.82 & 47.22 & 47.37 & $59.73^{\mathrm{a}}$ \\
\hline & $15 \mathrm{~g}$ & 25.18 & $30.63^{\mathrm{ab}}$ & 70.38 & 45.67 & 45.40 & $67.62^{\mathrm{ab}}$ \\
\hline Vitamin C & $400 \mathrm{mg}$ & 23.38 & $34.35^{\mathrm{ab}}$ & 73.5 & 49.84 & 42.95 & $69.41^{\mathrm{ab}}$ \\
\hline SEM* & & 1.14 & 1.39 & 3.3 & 0.97 & 2.63 & 2.72 \\
\hline $\begin{array}{l}\text { Weekly } \\
\text { Mean }\end{array}$ & & $28.05^{\mathrm{A}}$ & $33.53^{\mathrm{A}^{*}}$ & $59.50^{\mathrm{B}}$ & $49.93^{\mathrm{B}^{*}}$ & $50.06^{\mathrm{C}}$ & $67.38^{\mathrm{C}^{*}}$ \\
\hline \pm SEM & & \pm 1.24 & \pm 1.40 & \pm 3.72 & \pm 1.06 & \pm 3.00 & \pm 2.77 \\
\hline
\end{tabular}

Values with different superscript and superscript with asterisk within the column and across the row respectively are significantly different $(p<0.05)$.; TREAT= Treatment, MCH= Mean corpuscular haemoglobin; MCHC= Mean corpuscular haemoglobin concentration; $W B C=$ White blood cell count .Haemoglobin concentration; MCV=Mean corpuscular volume; Wk=Week; SEM* = Pooled standard error of mean

It could however be concluded that the spices have no negative effects on Hbc since the values at both beginning and the end of the experiment were within the range for rabbit (Mitruka and Rawnsley, 1977). White blood cell was also not significantly different $(p>0.05)$ among the experimental treatments both at the beginning and the end of the experiment. This result was similar to the report of Ugwu and Omale, 2011 who observed non - significant WBC values in rat fed onion and garlic extracts. Nonetheless, WBC observed in this study was within the normal range for the rabbit (Burke, 1994; Research Animal Resources, 2009). At the beginning and end of the study $\mathrm{MCH}, \mathrm{MCHC}$ and MCV values were not significantly different $(\mathrm{p}>0.05)$ ) among the experimental animals, though their overall means were significantly higher at the end of the study with the exception of $\mathrm{MCHC}$ with a lower overall mean. MCV (42.86 - 59. 13) at the beginning of the study was below the range observed for the rabbit (Research Animal Resources, 2009) suggesting that the experimental animals had subnormal sized RBC. At the end of the study, $\mathrm{MCH}$ and MCV values were within the established values for rabbit (Research Animal Resources, 2009) and also higher than the initial values which indicated that the diet with or without spice supplementation normalised the sizes of the RBC which is suggestive of the absence of anaemia in the animals (Enitan et al., 2012; NseAbasi et al., 2014). MCHC non-significant difference among the treatments corroborated the conclusions of Enitan et al., 2012. However, despite MCHC lower overall mean at the end of the study, values among the experimental animals were still higher than the normal range reported by Olabanji 
et al. (2007). In general, the haematological condition observed in the experimental animals could be due to adequate protein provided by the experimental diets and the antioxidant activities of phytochemicals in the ingested spices which maintained the haematopoietic and erythropoietic functions of the bone marrow (NseAbasi et al., 2014) even under a severe heat stress condition.

Total antioxidant capacity (TAC) of the experimental animals ranged from 45.60 $86.99 \mathrm{mgAE} / \mathrm{m}$ at the beginning of the experiment. Animals allotted to garlic at $5 \mathrm{~g} / \mathrm{kg}$ feed had a significantly lower value and could be ascribed to the inherent nature of these animals since they had not been fed with the supplemented diets at the time. TAC at the middle (weeks 5) and end of the experiment (week 8) was not significantly different $(p>0.05)$ among the experimental animals (Table 06). This result was similar to the findings of Ghalehkandi, 2014 who found that
TAC of garlic treated rats and the control was not significantly different regardless of the level of inclusion.

TAC fluctuated among the treatments groups with most groups having higher numerical TAC values at the end of the study than at the beginning though the weekly means were not significantly different. This implied that the ingested spices did not reduce the animals' TAC in agreement with the reports of Khaki et al., 2012. Generally, the fluctuating TAC trend observed in this study could be attributed to the physiological adjustment of the experimental animals to maintain equilibrium (Moberg, 2000) in the production and eradication of reactive oxygen species under external environmental stressors one of which was sustained heat stress observed in this study.

Table 06: $\quad$ Effect of spice - supplemented diet on the total antioxidant capacity of the blood serum of rabbit bucks

\begin{tabular}{ccccc}
\hline & & \multicolumn{3}{c}{ TAC $(\mathrm{mgAE} / \mathrm{m})$} \\
\cline { 3 - 5 } Treatment & TRTL & Week 1 & Week 5 & Week 8 \\
\hline Control & 0 & $79.29^{\mathrm{b}}$ & $85.66^{\mathrm{b}}$ & 84.60 \\
& $5 \mathrm{~g}$ & $73.58^{\mathrm{b}}$ & $88.64^{\mathrm{b}}$ & 84.93 \\
Ginger & $10 \mathrm{~g}$ & $78.78^{\mathrm{b}}$ & $70.29^{\mathrm{ab}}$ & 75.04 \\
& $15 \mathrm{~g}$ & $82.27^{\mathrm{b}}$ & $62.99^{\mathrm{a}}$ & 78.07 \\
Garlic & $5 \mathrm{~g}$ & $45.60^{\mathrm{a}}$ & $79.76^{\mathrm{ab}}$ & 99.05 \\
& $10 \mathrm{~g}$ & $83.82^{\mathrm{b}}$ & $82.91^{\mathrm{b}}$ & 91.77 \\
& $15 \mathrm{~g}$ & $80.40^{\mathrm{b}}$ & $78.31^{\mathrm{ab}}$ & 88.12 \\
Onion & $5 \mathrm{~g}$ & $83.39^{\mathrm{b}}$ & $85.37^{\mathrm{b}}$ & 86.31 \\
& $10 \mathrm{~g}$ & $81.70^{\mathrm{b}}$ & $81.70^{\mathrm{ab}}$ & 84.29 \\
Vitamin C & $15 \mathrm{~g}$ & $86.99^{\mathrm{b}}$ & $82.23^{\mathrm{ab}}$ & 101.36 \\
SEM* & $400 \mathrm{mg}$ & $79.67^{\mathrm{b}}$ & $74.95^{\mathrm{ab}}$ & 79.45 \\
Weekly mean \pm SEM & & 2.48 & 1.93 & 2.87 \\
\hline
\end{tabular}

Values with different superscript within the column are significantly different $(p<0.05)$, SEM $M^{*}=$ Pooled standard error of mean; $T R T L=$ Treatment level; $T A C=$ Total antioxidant capacity $S E M=$ Standard error of mean 


\section{CONCLUSIONS}

The adverse effect of heat stress observed in this study was more apparent on sperm morphology than other semen parameters though ginger at $5 \mathrm{~g} / \mathrm{kg}$ feed ameliorated the impact most among spice supplementations. The finding of the current study showed that heat stress and spices supplementation were not deleterious on the haematological parameters and the serum total antioxidant capacity of the experimental rabbit. Further research with the spices combined and at higher supplementation levels is recommended.

\section{REFRENCES}

Ain-Baziz, H., Boulbina, I., Ilès, I., Belabbas, R., Zenia, S. and Temim, S. (2012). Influence of environmental temperature and relative humidity on semen characteristics in male rabbit (Oryctolagus cuniculus) of local Algerian population. Proceedings 10th World Rabbit Congress - September 3 - 6, 2012-Sharm El- Sheikh -Egypt, 347- 350.

Akinsola, O. M. (2012). Genetic and physiological evaluation of Hyla rabbits in guinea savannah zone of Nigeria, Zaria: M.Sc. dissertation submitted to the Department of Animal Science, Ahmadu Bello University.

Akpa, G.N., Yahaya, H.K. and Martin U.C. (2012). The effects of age, breed, sire, body weight and the ejaculate characteristics of rabbit bucks. International Journal of Animal and Veterinary Advances 4(3): 191-194.

Al-Eissa M. S., Alhamidi A.R., Mohamed, A. S., Ibraheem A.S., Hamad A., Al-Farraj, S., Saad A. and Al-Dahmash B. (2011). Scrotal, testicular and semen characteristics of the mountain gazelle males (Gazella gazella). African Journal of Microbiology Research, 5(28): 5137-5141.https:// doi.org/ 10.5897/AJMR11.1234

Ayyat, M.S. \& Marai, I.F.M. (1997). Effects of heat stress on growth, carcass traits and blood antioxidants on post-thawed Angora goat (Capra hircus ancryrensis) sperm parameters, lipid peroxidation and antioxidant activities. Small Ruminant Research, 89(1): 24-30.

Burke, J. (1994). Clinical care and medicine of pet rabbit. Proceedings of the Michigan Veterinary Conference: 49-77.

Chenoweth, P.J. (2005). Genetic sperm defects. Theriogenology, 64 (3): 457-468.http: //doi.org/ 10.1016/j.theriogenology.2005.05.005

Daramola, J. O., Adeloye, A. A., Fatoba, T. A. and Soladoye, A. O. (2005). Haematological and biochemical parameters of West African Dwarfgoats. Livestock Research for Rural Development, 17(8). Available at: http://www.lrrd.org/lrrd17/8/dara17095.htm.

El-Maghawry, A. M. \& Soliman, M.M. (2002). Rabbit semen quality as affected by breed, feeding time, kindling season and weight of buck. Egyptian Journal of Rabbit Science, 12(2): 133-142.

El-Sayed, A., Iraqi, M.M., Elwan, K., Team, F. E. I. and El-Hanafy, A. (2016). Seasonal variation in libido and semen characteristics of Sinai Gabali rabbits. Arab Journal of Nuclear Science and Applications, 94 (4): 160-166.

El-Speiy, M. E. \& El-Hanoun, A.M. (2013). Effect of ginger extract on reproductive performance of male rabbits. Egyptian Poultry Science, 33 (1): 261-277.

El-Tarabany, M.S., El-Bayomi, K. and Abdelhamid, T. (2015). Semen characteristics of purebred and crossbred male rabbits. PLOSONE 10 (5): 1 - 9.http: //doi.org/10.1371/journal.pone.0128435 
Enitan, S. S., Ajeigbe, K. O., Josiah, S. J. and Ehiaghe, F. A. (2012). Haematological and hepatotoxic potential of onion (Allium cepa) and garlic (Allium sativum) extracts in rats. European Journal of Medicinal Plants 2(4): 290-307. http: //doi.org/ 10.9734/EJMP/2012/1517

Ewuola, E. O. \& Egbunike, G. N. (2008). Haematological and serum biochemical response of growing rabbit bucks fed dietary fumonisin B1. African Journal of Biotechnology, 7 (23): 4304-4309.

Ewuola, E.O., Jimoh, O.A., Atuma, O.V. and Soipe, O.D. (2012). Haematological and serum biochemical response of growing rabbits fed graded levels of Moringa oleifera leaf meal. Proceedings of the 10th World Rabbit Congress, Sharm El- Sheikh -Egypt: 679 - 683.

Finzi A., Daader A., Yamani K., Soliman A., Askara A. (2000). Influence of chronic high relative humidity on semen quality of hot stressed bucks. 7th World Rabbit Congress, 4-7 Jully, Valencia (Spain), 8.

Galvin, J. F. P. (2009). The weather and climate of the tropics - Climate, flora and fauna. Weather, 64(4): $100-108$.

Ghalehkandi, J. G. (2014). Garlic (Allium sativum) juice protects from semen oxidative stress in male rats exposed to chromium chloride. Animal Reproduction, 2 (4): 526-532.

Habeeb, A.A.M., Aboul-Naga, A.I. and Khadr, A.F. (1999): Deterioration effect of summer hot climate on bunnies of acclimatized rabbits during suckling period. In: 1st International Conference on Indigenous versus Acclimatized Rabbits, El-Arish, North Sinai, Egypt, 253-263.

Hammami, I., Nahdi, A., Mauduit, C., Benahmed, M. and Amri, M. (2008). The inhibitory effects on adult male reproductive functions of crude garlic (Allium sativum) feeding. Asian Journal of Andrology, 10(4): 593-601. http: //doi.org/ 10.1111/j.1745-7262.2008.00358.x

Hansen, P. J. (2009). Effects of heat stress on mammalian reproduction. Philosophical Transaction of the Royal Society B., 364: 3341-3350. http: //doi.org/ 10.1098/rstb.2009.0131

I.R.R.G. (International Rabbit Reproduction Group). (2005). Guidelines for the handling of rabbit bucks and semen. World Rabbit Science, 13: $71-91$.

Ige, S.F. \& Akhigbe, R.E. (2012). The role of Allium cepa on aluminum-induced reproductive dysfunction in experimental male rat models. Journal of Human Reproduction Science, 5(2): 200 - 205. http: //doi.org/ 10.4103/0974-1208.101022

Iraqi, M.M., Radwan, A. A., Gado, M. S., El-Sayed, A.I. and Elokil, A.A. (2012). Evaluation of semen characteristics in a project of synthesizing new line of rabbits in Egypt.1st International Conference on Biotechnology Application: In Faculty of Agriculture, Banha University, Moshtohor and Hurghada, Egypt.

Jain, N.C. (1986). Scanning electron micrograph of blood cells. In: Schalm's Veterinary Haematology (4th edition). Published by Lea and Febiger. Philadelphia: 4: 63-70.

Prieto, P., Pineda, M. and Aguilar, M. (1999). Spectrophotometric quantitation of antioxidant capacity through the formation of a phosphomolybdenum complex: Specific application to the determination of vitamin E. Analytical Biochemistry, 269: 337-341.http: //doi.org/ 10.1006/ abio.1999.4019

Khaki, A., Fathiazad, F., Nouri, M., Khaki, A.A., Ozanci, C.C., Ghafari-Novin, M. and Hamadeh, M. (2009).The effects of Ginger on spermatogenesis and sperm parameters of rat. Iranian Journal of Reproductive Medicine, 7(1): 7-12. 
Marai, I.F.M., Habeeb, A.A.M., and Gad, A.E. (2002). Rabbits' productive, reproductive and physiological performance traits as affected by heat stress: a review. Livestock Production Science, 78: 71-90. http: //doi.org/10.1016/s0301-6226 (02)00091-x

Mitruka, B. M. \& Rawnsley, H. M. (1977). Clinical, biochemical and haematological reference values in normal experimental animals. Masson Publishing Inc., United State of America: 134-135.

Moberg, G.P. (2000). Biological response to stress: implications for animal welfare. In: The biology of animal stress (G.P Moberg and J.A Mench Ed. ). Published by CAB Publishing International: $16-36$.

Morakinyo, O.A., Achema, P. and Adegoke O. (2010). Effect of Zingiber officinale (ginger) on sodium arseniteae; induced reproductive toxicity in male rats. African Journal of Biomedical Research, 13(1):39-45.

Nagendra, S. C., Vikas, S., Dixit, V. K. and Mayank, T. (2014). A review on plants used for improvement of sexual performance and virility. Hindawi Publishing Corporation, BioMed Research International: 1 - 20.http: //doi.org /10.1155/2014/868062

Najmul, K. (2015). Effect of garlic and ginger supplementation on growth performance of broiler rabbit. A MSc. thesis submitted to the Department of Animal Science and Nutrition Faculty of Veterinary Medicine Chittagong Veterinary and Animal Sciences University, Khulshi, Chittagong, Bangladesh.

Nemec, A., Drobniâ-Koorok, M., Skitek, M., Pavlica, Z., Galac, S. and Butinar, J. (2000). Total antioxidant capacity (TAC) values and their correlation with individual antioxidants in serum of healthy beagles. Acta Veterinaria Brno, 69: 297-303.

Nizza A., Di Meo C., Taranto S. (2003). Effect of collection rhythms and season on rabbit semen production. Reproduction in Domestic Animals, 38: 436- 439.http: //doi.org/10.1046/j.14390531.2003.00458.x

NseAbasi, N. E., Williams, M. E., Uduak, A., and Edem, E. A. O. (2014). Haematological parameters and factors affecting their values. Agricultural Science, 2(1): 37-47. http: //doi.org/10.12735/ as.v2i1p37

Ogbuewu I.P., Okoli I.C., and Iloeje M. U. (2013). The detrimental effect of dietary ginger rhizome powder supplementation on reproductive performance of pubertal rabbit bucks. International Journal of Innovation and Applied Studies, 4(1): 128-132.

Okab, A.B., El-Banna, S.G. and Koriem A.A. (2008). Influence of environmental temperatures on some physiological and biochemical parameters of male New-Zealand rabbits. Slovak Journal of Animal Science, 41: 12-19.

Ola, S.I. (2016). OLIRAV: A simple, disposable rabbit artificial vagina: service/procedure. Proceedings of the 11th World Rabbit Congress, Qingdao-China: 209-212.

Olabanji, R. O., Farinu, G. O., Akinlade, J. A. and Ojebiyi, O. O. (2007). Growth performance and haematological characteristics of weaner rabbits fed different levels of wild sunflower (Tithonia diversifolia Hems L A. Gray) leaf blood meal mixture. Proceedings of the 32nd Animal Conference of Nigeria Society for Animal Production, 207-209.

Omotoso, G., Oyewopo, A., Kadir, A., Olawuyi, S.and Jimoh, A. (2009). Effects of aqueous extract of Allium Sativum (garlic) on semen parameters in wistar rats. The Internet Journal of Urology, 7 (2): 1-3. 
Onu, P.N and Aja, P.M. 2011. Growth performance and haematological indices of weaned rabbits fed garlic (Allium sativum) and ginger (Zingiber officinale) supplemented diets. International Journal of Food, Agricalture and Veterinary Science, 1: 51-59. Available at http://www.cibtech. org/jfav.htm

Oseni, S.O. and Lukefahr, S.D. (2014). Rabbit production in low-input systems in Africa: Situation, knowledge and perspectives - a review. World Rabbit Science, 22: 147-160.http: //doi. org/10.4995/wrs.2014.1348

Pawar, V. S. and Hugar, S. (2012). A current status of adaptogens: natural remedy to stress. Asian Pacific Journal of Tropical Disease, 2 (1): 24 - 31.http: //doi.org/10.1016/S2222-1808 (12)60207-2

Prieto, P., Pineda, M. and Aguilar, M. (1999). Spectrophotometric quantitation of antioxidant capacity through the formation of a phosphomolybdenum complex: Specific application to the determination of vitamin E. Analytical Biochemistry, 269: 337-341.http: //doi.org/10.1006/ abio.1999.4019.

Ramandeep, S., Ashraf, A., Jeyabalan, G., Semwal, A. and Jaikishan. (2013). An overview of the current methodologies used for evaluation of aphrodisiac agents. Journal of Acute Disease: 8591.https://doi.org/10.1016/S2221-6189 (13)60105-5

Research Animal Resource. (2009). Reference values for laboratory animals: Normal haematological values. University of Minnesota. Available at: http://www.ahc.umn.edu/rar/refvalues.html.

Rubio, C. P., Hernández-Ruiz, J., Martinez-Subiela, S., Tvarijonaviciute, A. and Ceron, J. J. (2016). Spectrophotometric assays for total antioxidant capacity (TAC) in dog serum: an update. BMC Veterinary Research, 12(166):1-7. https://doi.org/10.1186/s12917-016-0792-7.

Schneidgenová, M., Vašíček, J., Čupka, P. and Chrenek, P. (2011). Is it necessary to control seasonal quality of the rabbit ejaculate? Slovak Journal of Animal Science, 44: 48 - 51.

Shinkut Matthew. (2015). Semen characteristics, gonadal sperm reserves and haematological parameters of rabbit bucks fed diets supplemented with Allium sativum (garlic). A Master thesis submitted to the School Of Postgraduate Studies, Ahmadu Bello University, Zaria.

Shinkut, M., Rekwot, P. I., Nwannenna, I, A. and Bugau, J. S. (2016). Spermiogram of rabbit bucks fed diets supplemented with Allium sativum (garlic). IOSR Journal of Agriculture and Veterinary Science, 9(2): 20-26.https://doi.org/10.9790/2380-09222026

Trewin, B. (2014). The climates of the Tropics and how they are changing. In: State of the Tropics 2014 Report (Harding, S., McComiskie, R., Wolff, M., Trewin, D., Hunter, S. (Eds.). James Cook University, Cairns, Australia: 39-52. Available at: http://stateofthetropics.org/wp-content/ uploads/Essay-1-Trewin.pdf.

Ugwu, C.E. and Omale, J. (2011). Comparative effects of aqueous garlic (Allium sativum) and onion (Allium cepa) extracts on some haematological and lipid indices of rats. Annual Review and Research in Biology, 1(3): 37-44. 